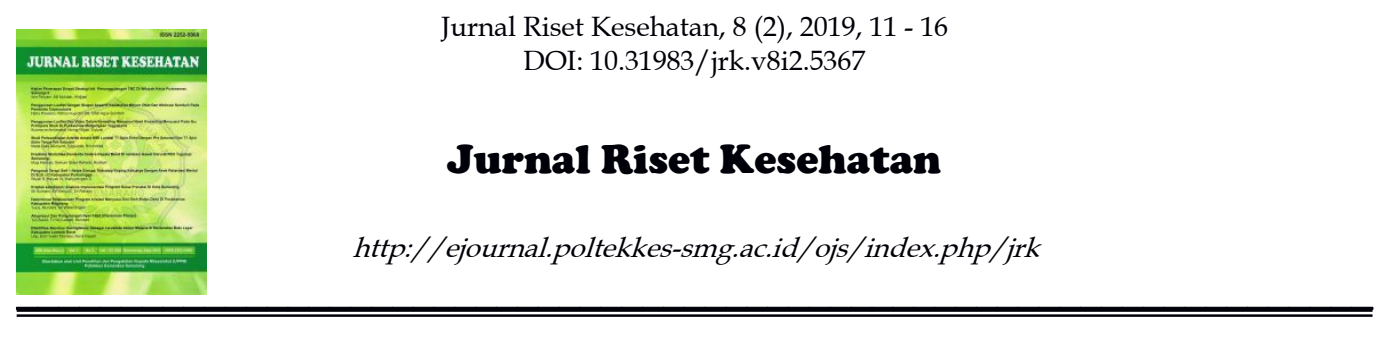

\title{
LEVELS OF MINERALS, VITAMIN AND POWER RECEIVED IN DRINK INFUSED WATER WITH DIVERSIFICATION
}

\author{
Surati $^{\mathrm{a}^{*}}$; SY. Didik Widiyanto ${ }^{\mathrm{b}}$; Nurul Qomariyah ${ }^{\mathrm{c}}$; Ririh Jatmi Wikandari ${ }^{\mathrm{d}}$ \\ a,b,c,d Departement of Health Analyst ; Poltekkes Kemenkes Semarang; \\ Woltermonginsidi 115 ; Semarang 50192 ; Indonesia
}

\begin{abstract}
Infused water is drinking water that has been given additional pieces of fruit so that the water gives a certain sensation of water. Infused water are consumed by the community because the manufacturing process is easy and use local fruits. To determine the vitamin content $(\mathrm{A}$ and $\mathrm{C})$, mineral content $(\mathrm{K}, \mathrm{Ca}, \mathrm{Mg})$ and acceptability of infused water with sample codes (A, B and C). The benefits of this study are to be able to add to the list of healthy and nutritious drinks that are beneficial for health because infused water contains vitamins and minerals. Experiments with Complete Random Design (CRD), Sample code A, B and C in the analysis of vitamin levels, mineral content and acceptability. Acceptance analysis was carried out Friedman test and Wilcoxon test. Vitamin and mineral levels were analyzed by ANOVA and LSD statistics. Infused water contains mineral potassium, calcium and magnesium and contains vitamins $\mathrm{A}$ and $\mathrm{C}$, there are significant differences between the sample code A, B and C. Infused water containing minerals, vitamins, and accepted by the community.
\end{abstract}

Keywords: infused water; minerals ; vitamins and acceptability

\section{Introduction}

Based on the regulation of the Minister of Health of the Republic of Indonesia Number (Anonim, 2010), what is meant by drinking water is water through processing or processing that meets health requirements and can be drunk directly. As for drinking water supervision requirements include: Bacteriology, Chemistry, active radio and physics (Apriliana, 2014). The definition of drinking water can also be seen in the Decree of the Minister of Industry and Trade of the Republic of Indonesia (Anonim, 2004) concerning: Technical Requirements for its Water and Trade Water Depots. In the decision it was stated that drinking water is raw water that has been processed and processed for drinking. Ideal drinking water is raw water that has been processed and processed for drinking. Ideal drinking water should be clear, colorless,

*) Corresponding Author (Surati)

E-mail: analis_surati@yahoo.com tasteless and odorless, and not contain pathogenic germs and chemicals that can interfere with bodily functions (Apriliana, 2014).

Drinking water is one of the main needs for humans. Drinking water is water that goes through a process of processing or without processing that meets health requirements and can be drunk directly. Good drinking water is water that meets requirements such as being free from contamination of microorganisms and dangerous chemicals that are tasteless, colorless and odorless (Apriliana, 2014).

Clean water must have high quality, including three conditions, namely physical, chemical and biological to prevent disease, we drink with water every time, the water we consume must meet the water quality standard requirements in accordance with the Indonesian national standard (SNI). Physical requirements include water that must be clear or not cloudy, 
colorless water, tasteless water or tasteless, water odorless, normal temperature and no solid matter. Chemical conditions include neutral $\mathrm{pH}$, does not contain toxic chemicals, does not contain salts or metal ions, low hardness and does not contain organic matter. Bacteriological requirements include water that does not contain pathogenic bacteria, for example e. coli bacteria, salmonella typhi and water should not contain non-pathogenic bacteria such as coliform. Humans need water to drink, various kinds of beverages, for example mineral water which is packed in various forms and various brands, mineral water is not enough so that flavored beverage products such as tea, coffee, juice, soda and infused water drinks appear (Bambang, 2014).

Infused Water or also known as spa water is water that is given additional pieces of fruit and then allowed to stand a few hours until the juice comes out, can be left in the refrigerator for 4-12 hours, then ready to be consumed, thus providing flavor and health benefits. In this way, the water consumed becomes more flavorful and fresh (Haitami et all, 2017).

Infused water is water that has been given additional pieces of fruit or herbs (ginger, cinnamon, etc.) so that the water gives a certain sensation of water and is beneficial for health. The basic ingredient in making infused water is water so that the water used must be considered quality. Fruits before use are washed clean of various impurities, skin and fruit directly used in the process of making infused water, the fruits are sliced transversely then put in one liter of water placed in a bottle and stored in the refrigerator at least 2 hours so that the fruit - the substance secretes vitamins and minerals and creates a different sensation. Infused water drinks are becoming known and consumed by some Indonesians because the manufacturing process is very easy, easy to obtain fruits and infused water are beneficial for health because infused water drinks contain vitamins and minerals. Vitamins and minerals in infused water come from these fruits (Haitami et all, 2017).

Infused water is one of the drinks that tastes and is very easy in the process of making it necessary to know the vitamin content $(\mathrm{A}, \mathrm{C}, \mathrm{E})$, mineral content $(\mathrm{K}, \mathrm{Ca}, \mathrm{Mg})$ and the acceptance of infused water so that the drink is said to be a drink nutritious (Mohammad Arif Ali, 2018). Based on the description above, the researchers wanted to examine the levels of vitamins and minerals in the infused water with different diversification of storage.

\section{Method}

This type of research includes the type of experimental research used to test existing hypotheses so that the influence between variables is known. The experimental design used in this study was a completely randomized design (CRD) with an independent variable namely infused water while the dependent variable was an infused water nutrient (vitamins, minerals and receptivity). So repetition is used in each sample treatment 4 times, so the sample will be made 12 units of sample.

\section{Result and Discussion}

This research was conducted for three months starting from September to November 2017. The manufacture of infused water products (code samples A, B and C) and organoleptic tests were carried out in the food technology laboratory at the Department of Nutrition, Poltekkes Kemenkes Semarang. Calcium and magnesium tests on infused water drinks were carried out at the Health Laboratory and Testing Medical Devices while the potassium and vitamin $C$ tests were carried out at the Center for Industrial Pollution Prevention Technology at the Ministry of Industry.

Table 1. Recapitulation of Organoleptic Test Results.

\begin{tabular}{cccccccccc}
\hline & \multicolumn{3}{c}{ Aroma } & \multicolumn{3}{c}{ Flavour } & \multicolumn{3}{c}{ Color } \\
\cline { 2 - 12 } & A & B & C & A & B & C & A & B & C \\
\hline 1 & 0 & 0 & 1 & 1 & 6 & 1 & 1 & 7 & 0 \\
\hline 2 & 2 & 8 & 11 & 4 & 12 & 6 & 4 & 13 & 0 \\
\hline 3 & 3 & 12 & 12 & 9 & 5 & 15 & 14 & 5 & 0 \\
\hline 4 & 13 & 3 & 1 & 10 & 2 & 3 & 5 & 0 & 0 \\
\hline 5 & 7 & 2 & 0 & 1 & 0 & 0 & 1 & 0 & 0
\end{tabular}

Remarks: really like (1), like (2), rather like (3), dislike (4), really dislike (5)

Based on table 1. Shows that the most preferred product with a sequence of sample $B$ code, sample code A and sample code C. Taste with the category very like is product $\mathrm{B}$ is the highest that is $24 \%(6 / 25 \times 100)$ compared to products $\mathrm{A}$ and $\mathrm{C}$ which is $4 \%(1 / 25 \times 100)$, the taste with the likes category is $48 \%$ while for the parameters it is very dislike $0 \%$ this shows that the sample code B is the most preferred.

Color with very like category is product B which is the highest, which is $28 \%$ compared to products $\mathrm{A}$ and $\mathrm{C}$ which is $4 \%$, Color with 
category likes 52\%, while for parameters it doesn't like $0 \%$ this shows that sample code B is the most preferred color. Aroma with the likes category is the highest product $\mathrm{B}$, which is $32 \%$, while for the parameter it is very dislike $8 \%$, this shows that the aroma code B sample is the most preferred.

The results of the aroma of infused water test have significant differences $(p=0.000)$, the results of the Wilcoxon taste difference between the three sample codes are taste (code sample A) with taste (sample code B) there is a difference (0.025), Taste (sample code A) with taste (code sample C) there is a difference in taste (0.001) and taste (code sample B) with taste (code sample C) also there is a difference in taste (0.001).

The results of the friedman aroma of the infused water drink have significant differences $(p=0.001)$, the results of the Wilcoxon different aroma (code sample A) with aroma (code sample B) there are differences (0.072), aroma (sample code A) with aroma (code sample C) there is a difference in aroma (0.006) and aroma (code sample B) with aroma (code sample C) also there is a difference in taste (0.001). The results of the friedman color test for infused water have significant differences $(p=0.000)$, the results of the Wilcoxon test are different colors (code sample A) with colors (sample code B) there are differences (0.000), colors (sample code A) with color (code sample $\mathrm{C}$ ) there are different colors (0.084) and colors (code sample B) with colors (sample code C) also have different colors (0.000).

Based on the recapitulation of the hedonic test forms on 3 infused water products, a number of 25 rather trained panelists about taste, aroma and color, from the three parameters there was a significant difference between taste and aroma, taste with color and between taste and aroma.

Code samples A, B and C have significant differences between the taste, aroma and color of the three sample codes. the most preferred product with the code sequence sample B (5 pieces of lemon, 3 strawberries and 5 mint leaves), code sample A (10 pieces of lemon) and code sample C ( 5 pieces of lemon, 5 pieces of cucumber and 5 pieces mint leaves).

Sample codes A, B, and C have a significant difference between the taste, aroma and color of the three sample codes. Taste of drinks infused water in sample code $\mathrm{A}=16 \%, \mathrm{~B}=48 \%$ and $\mathrm{C}=$ $24 \%$. The aroma of infused water in sample code $\mathrm{A}=8 \%, \mathrm{~B}=32 \%$ and $\mathrm{C}=44 \%$. And the color of infused water in sample code $\mathrm{A}=16 \%, \mathrm{~B}=52 \%$ and $\mathrm{C}=4 \%$.

The sample code B (5 pieces of lemon, 3 strawberry and 5 mint leaves) is the sample code most favored by 25 rather trained panelists because it is pink from strawberry fruit, a slightly sour taste of lemon and there is a sensation of the taste of leaves mint.

Table 2. Result of analysis calcium levels in infused water drinks.

\begin{tabular}{cccccc}
\hline Group & $\mathrm{N}$ & Mean & $\pm S D$ & Min & Max \\
\hline A & 4 & 163.81 & 1.65 & 162.00 & 166.00 \\
\hline B & 4 & 120.37 & 0.86 & 119.20 & 121.20 \\
\hline C & 4 & 140.12 & 0.82 & 139.20 & 141.20 \\
\hline
\end{tabular}

Based on table 2. showed that the mean calcium content was highest in group A which was $163.81( \pm \mathrm{SD}=1.65)$ and the lowest in group $\mathrm{B}$ was $120.37( \pm \mathrm{SD}=0.86)$.

Table 3. Result of ANOVA test.

\begin{tabular}{ll}
\hline \multicolumn{1}{c}{ Variable } & Sig. \\
\hline Calcium levels between groups & 0.00 \\
\hline Magnesium levels between groups & 0.00 \\
\hline Potassium levels between groups & 0.00 \\
\hline
\end{tabular}

Based on table 3. showed that there were significant differences between the sample code A, B and C. ANOVA test results showed that there were differences in calcium levels between groups $(p=0.000)$.

Calcium levels in infused water with sample code A, B and C with a value of $p>0.05$ so that the data is normally distributed. Based on table 3. Calcium levels in infused water drinks with code samples A, B and C in the previous chapter. The highest calcium content in the sample code A (600 ml of water (aqua) added with 2 lemons cut thinly) then code sample $C$ (600 $\mathrm{ml}$ of water (aqua) plus 5 pieces of lemon and 5 pieces of cucumber) and the lowest calcium level in the sample code B $(600 \mathrm{ml}$ of water (aqua) plus 3 strawberries, 5 pieces of lemon and 5 mint leaves).

The highest calcium content in the sample code A $(600 \mathrm{ml}$ of water (aqua) plus 2 thinly sliced lemons) is supported because the lemon contains calcium content before the infused water is made in the literature review chapter.

According to (Florencia, 2014) research that refill water used as the base material for making infused water drinks contains calcium \pm 0.2868 $\mathrm{mg} /$ liter and magnesium $\pm 0.1143 \mathrm{mg} /$ liter. This research made three infused water products with research codes A, B and C. All infused beverage 
products contain calcium content which is beneficial to the health of the body. The basic ingredients of making infused water drinks from drinking water and fruit (lemon, cucumber, mint leaves and strawberry) used contain levels of calcium

According to (Widjaja, 2014) that bottled drinking water (AMDK) used as a base for making drinks infused water contains calcium $\pm 0.2868 \mathrm{mg} /$ liter and magnesium \pm 0.1143 $\mathrm{mg} /$ liter. This study made three products infused water with research codes A, B and C. All infused beverage products contain levels of calcium which are beneficial to body health. The basic ingredients of making drinks infused water both from drinking water and fruits (lemons, cucumbers, mint leaves, and strawberries) that are used contain calcium levels, this is supported by research (Sriwijaya, 2013) which states that cucumbers contain calcium levels $19 \mathrm{mg} / 100$ grams of raw cucumber.

Table 4. Results of analysis of magnesium levels in infused water drinks.

\begin{tabular}{cccccc}
\hline Group & $\mathrm{N}$ & Mean & \pm SD & Min & Max \\
\hline A & 4 & 20.32 & 0.74 & 20.24 & 20.42 \\
\hline B & 4 & 20.91 & 0.19 & 20.68 & 21.16 \\
\hline C & 4 & 21.96 & 0.14 & 21.83 & 22.12 \\
\hline
\end{tabular}

Based on table 4 showed that the highest magnesium level was highest in group $C$ which was $21.96( \pm \mathrm{SD}=0.14))$ and the lowest in group A was $20.32( \pm \mathrm{SD}=0.74)$.

Based on table 3. showed that there were significant differences between the sample codes $\mathrm{A}, \mathrm{B}$ and $\mathrm{C}$. The ANOVA test results showed that magnesium levels differed between groups $(p=$ 0,000).

Magnesium content in infused water with sample code A, B and C with a value of $p>0.05$ so that the data is normally distributed. Based on graph 5.3. Magnesium levels in infused water drinks with code samples $\mathrm{A}, \mathrm{B}$ and $\mathrm{C}$ in the previous chapter. The highest magnesium levels in the sample code C, B and the lowest magnesium levels in the sample code A.

The highest magnesium content in the sample code C (600 $\mathrm{ml}$ of water (aqua) plus 5 pieces of lemon, 5 pieces of cucumber and five mint leaves) is supported because the lemon contains magnesium content before the infused water is made in chapter literature review.

According to (Florencia, 2014) research that refill water used as the base material for making infused water drinks contains calcium \pm 0.2868 $\mathrm{mg} /$ liter and magnesium $\pm 0.1143 \mathrm{mg} /$ liter. This study made three infused water products with research codes A, B and C. All infused beverage products contain magnesium levels which are beneficial to the health of the body. The basic ingredients of making drinking water and fruit infused water drinks (lemon, cucumber and mint leaves) used contain magnesium levels. In accordance with the theoretical basis that lemon contains magnesium $\pm 8.0 \mathrm{mg}$ and mint leaves contain magnesium $\pm 16.0 \mathrm{mg}$.

According to (Haryo, 2015) research that giving an infused water combination of cucumber with red wine can reduce blood pressure in adult men.

Table 5. Results of analysis of potassium levels in infused water drink.

\begin{tabular}{cccccc}
\hline Group & $\mathrm{N}$ & Mean & \pm SD & Min & Max \\
\hline A & 4 & 143.43 & 28.95 & 124.15 & 176.72 \\
\hline B & 4 & 143.73 & 29.33 & 124.22 & 177.47 \\
\hline C & 4 & 143.58 & 29.14 & 124.19 & 177.10 \\
\hline
\end{tabular}

Based on table 5 showed that the highest average potassium level in group B was 143.73 ( \pm $\mathrm{SD}=29.33$ ) and the lowest in group B was 143.43 $( \pm \mathrm{SD}=28.95)$. Based on table 3 showed that there were significant differences between the sample code A, B and C. The ANOVA test results showed that potassium levels differed between groups $(p=0,000)$. Different tests between sample codes $A B, A C$ and $B C$ have significant differences $(p=0.000)$.

Potassium content in infused water with sample code A, B and C with a value of $p>0.05$ so that the data is normally distributed. Based on table 5. Potassium levels in infused water with sample code A, B and C in the previous chapter. The highest potassium level in the sample code $B$, $\mathrm{C}$, and the lowest potassium level in the sample code A. The highest potassium level in the sample code B (600 ml of water (aqua) plus 5 pieces of lemon, 3 strawberries and five leaves mint) this is supported because lemon and mint leaves already contain potassium levels before infused water is made in the literature review chapter.

All infused beverage products contain potassium levels that are beneficial to the health of the body. The basic ingredients of drinking water infused water and fruit (lemon and mint leaves) used contain potassium levels. In accordance with the theoretical basis that lemon contains $\pm 138 \mathrm{mg}$ of potassium and mint leaves containing magnesium $\pm 13 \mathrm{mg}$.

Based on the number of nutritional adequacy (RDA) for all age groups requires 
mineral levels of potassium, calcium and magnesium. Infused water drinks contain mineral levels of potassium, calcium and magnesium so that people can make and consume infused water drinks that are useful for health. The content of mineral content of potassium, calcium and magnesium in infused water is still below the requirements of AKG.

Table 6. Results of analysis of vitamin A levels in infused water drinks.

\begin{tabular}{cccccc}
\hline Group & $\mathrm{N}$ & Mean & \pm SD & Min & Max \\
\hline A & 4 & 0.50 & 0.008 & 0.49 & 0.51 \\
\hline B & 4 & 0.61 & 0.016 & 0.59 & 0.63 \\
\hline C & 4 & 0.37 & 0.008 & 0.36 & 0.38 \\
\hline
\end{tabular}

Based on table 6 showed that the highest vitamin A level was highest in group B which was $0.61( \pm S D=0.016)$ and the lowest in group $C$ was $0.37( \pm S D=0.008)$. Based on table 3 showed that there were significant differences between the sample code A, B and C. The ANOVA test results of vitamin A levels differed between groups $(p=0.000)$. Different tests between sample codes $A B, A C$ and $B C$ have significant differences $(p=0.000)$.

Vitamin A levels in infused water with sample code A, B and C with a value of $p>0.05$ so that the data is normally distributed. Based on table 6 vitamin A levels in infused water with sample code $\mathrm{A}, \mathrm{B}$ and $\mathrm{C}$ in the previous chapter. The highest vitamin A level in the sample code B, $\mathrm{A}$ and the lowest level of vitamin $\mathrm{A}$ in the sample code C.

The highest vitamin A level in the sample code B $(600 \mathrm{ml}$ of water (aqua) plus 5 pieces of lemon, 3 strawberries and five mint leaves) is supported because lemon, strawberry and mint leaves contain vitamin levels A before making an infused water in the literature review chapter.

Vitamin A in food has 4 structural compounds, namely retinol (Vitamin A1 alcohol), retinal (vitamin A aldehyde), retinoic acid (vitamin A acid), and retinil retinil palmitate ester (vitamin A ester/palmitate). Infused water is included in vitamin A acid or retinoic acid. Vitamin and provitamin A compounds are limpophilic because of their nonpolar structure. Vitamin A is easily oxidized, rather stable when heated in a vacuum and not exposed to light, unstable with ultraviolet, quite stable in alkaline conditions, and the presence of metals can accelerate the oxidation of vitamin A. Vitamin A is unstable in various applications and requires antioxidants to prolong the life save it.

All infused water products contain vitamin
A levels that are beneficial to the health of the body. The basic ingredients for making infused water drinks from drinking water and fruit (lemon, strawberry fruit and mint leaves) used contain levels of vitamin A (Indriani, 2015). In accordance with the basic theory that lemon contains vitamin $\mathrm{A} \pm 22 \mathrm{UI}$, strawberry fruit \pm 0.03 $\mathrm{UI}$ and mint leaves contain vitamin $\mathrm{A} \pm 26 \mathrm{UI}$

Table 7. Results of analysis of vitamin C levels in infused water drinks.

\begin{tabular}{cccccc}
\hline Group & $\mathrm{N}$ & Mean & \pm SD & Min & Max \\
\hline A & 4 & 0.10 & 0.005 & 0.10 & 0.11 \\
\hline B & 4 & 0.18 & 0.000 & 0.18 & 0.18 \\
\hline C & 4 & 0.08 & 0.020 & 0.07 & 0.11 \\
\hline
\end{tabular}

Based on table 6 showed that the highest average vitamin C level in group A was $0.10( \pm$ $\mathrm{SD}=0.005)$ and the lowest in group $\mathrm{C}$ was 0.008 $( \pm \mathrm{SD}=0.020)$.

Based on table 3 showed that there were significant differences between the sample code $\mathrm{A}, \mathrm{B}$ and $\mathrm{C}$. The ANOVA test results showed that vitamin $C$ levels differed between groups $(p=$ 0.000 ). Different tests between sample codes $A B$, $A C$ and $B C$ have significant differences $(p=$ $0.000)$.

Vitamin $C$ levels in infused water with sample code A, B and C with a value of $p>0.05$ so that the data is normally distributed. Based on table 7 vitamin $C$ levels in infused water with sample code A, B and C in the previous chapter. The highest vitamin $C$ level in the sample code B, $A$ and the lowest level of vitamin $C$ in the sample code C.

The highest vitamin $C$ level in the sample code B $(600 \mathrm{ml}$ of water (aqua) plus 5 pieces of lemon, 3 strawberries and five mint leaves) is supported because lemon, strawberry and mint leaves contain vitamin levels. C before making an infused water in the literature review chapter.

All infused beverage products contain vitamin $C$ levels that are beneficial to the health of the body. The basic ingredients of drinking water and fruit infused water drinks (lemon, strawberry fruit and mint leaves) used contain vitamin C. In accordance with the theoretical basis that lemon contains vitamin $\mathrm{C} \pm 53$, $\mathrm{mg}$ and mint leaves contain vitamin $\mathrm{C} \pm 22 \mathrm{mg}$.

Of all types of vitamins, vitamin $C$ is the most easily damaged type of vitamin. Vitamin $C$ is a type of vitamin that is most easily soluble in water and can take the form of ascorbic acid and dehydroascorbic acid. Both of these forms have activity as vitamin $\mathrm{C}$. The chemical structure of vitamin $C$ consists of a chain of $6 \mathrm{C}$ atoms and is 
unstable (C6H8O6), because it easily reacts with $\mathrm{O} 2$ in the air to dehydroascorbic acid. Vitamin C is easily damaged by oxidation by oxygen from the air. This process is accelerated by heat, light, alkali, enzym, the oxidizer is also an iron and copper catalyst. Oxidation will be slow if vitamin $C$ is in an acidic or low temperature state.

The low level of vitamin $C$ in the sample $C$ code is caused by the amount of free oxygen contained in the juice so that it causes high oxidation that can reduce vitamin $C$. The stability of ascorbic acid will increase with decreasing $\mathrm{pH}$ value. Vitamin $\mathrm{C}$ is stable in acidic media, but in neutral and alkaline media it is very easily degraded by heat (Farikha I, 2013).

Based on the number of nutritional adequacy (RDA) for all age groups requires vitamin $A$ and vitamin $C$. Infused water drinks contain vitamin $\mathrm{A}$ and vitamin $\mathrm{C}$ so that people can make and consume infused water drinks that are useful for health. The content of vitamin A and vitamin $C$ in infused water is still below the requirements of $\mathrm{AKG}$.

\section{Conclusion and Suggestion}

Vitamin A levels in infused water drinks were $0.61 \mathrm{mcg}$ (sample code B); $0.50 \mathrm{mcg}$ (sample code A) and $0.37 \mathrm{mcg}$ (sample code C). Vitamin $\mathrm{C}$ levels in infused water drinks are $0.18 \% \mathrm{v} / \mathrm{v}$ (sample code B); $0.10 \% \mathrm{v} / \mathrm{v}$ (code sample A) and $0.08 \% \mathrm{v} / \mathrm{v}$ (sample code C). Potassium levels in infused water drinks were $143.73 \mathrm{mg} / 1$ (sample code B); $143.58 \mathrm{mg} / 1$ (code sample C) and 143.43 $\mathrm{mg} / \mathrm{l}$ (sample code A). Calcium content in infused water drinks is $155.26 \mathrm{mg} / 1$ (sample code A); $140.07 \mathrm{mg} / 1$ (sample code C) and 120.37 $\mathrm{mg} / \mathrm{l}$ (sample code B). Magnesium levels in infused water drinks are $21.96 \mathrm{mg} / 1$ (sample code C); $20.94 \mathrm{mg} / 1$ (sample code B) and 20.33 $\mathrm{mg} / \mathrm{l}$ (sample code A). The most preferred power for infused water is sample code B, A and C. Infused water drinks all samples contain minerals and vitamins which are still below the nutritional adequacy rate (AKG).

\section{Acknowledgements}

I would give an appreciate to Director of Poltekkes Kemenkes Semarang. Mr. SY. Didik Widiyanto, SKM, M.Kes as chairman of the Department of Health Analyst of Poltekkes
Kemenkes Semarang and the Chief of The Research and Community Service.

\section{References}

Anonim. (2004). Kepmenperin No 651/MPP/kep/10/2004.

Anonim. Permenkes-No-492-Tahun-2010-Persyarata n-Kualitas-Air-Minum1.pdf.

Apriliana, E. et all. (2014). Bakteriological Quality Of Refill Drinking Water At Refill Drinking Water Depots In Bandar Lampung. JUKE, 74), 142-146.

Bambang, G. et all. (2014). Analisis Cemaran Bakteri Coliform dan Identifikasi Escherichia coli Pada Air Isi Ulang Dari Depot di Kota Manado. PHARMACON Jurnal IImiah Farmasi, 3(3), 325-334.

Farikha I, et all. (2013). Pengaruh Jenis Dan Konsentrasi Bahan Penstabil Alami Terhadap Karakteristik Fisikokimia Sari Buah Naga Merah ( Hylocereus polyrhizus ) Selama Penyimpanan. Jurnal Teknosains Pangan, 2(1), 30-38.

Florencia, M. (2014). Analisis Kalsium, Magnesium, Dan Timbal Pada Air Mineral Dalam Kemasan Dan Air Minum Isi Ulang Secara Spektrofotometri Serapan Atom.

Haitami et all. (2017). Kadar Vitamin C Jeruk Sunkist Peras Dan Infused Water. Medical Laboratory Technology Journal, 3(1), 98 102.

Haryo, R. (2015). Pengaruh Pemberian Infused Water Kombinasi Mentimun (Cucumis sativus) dan Anggur (Vitis vinifera) Terhadap Tekana Darah Pada Laki-laki Dewasa Muda.

Indriani, Y. dkk. (2015). Uji Aktivitas Antibakteri Air Perasan Buah Jeruk Lemon (Citrus limon osbeck) dan Madu Hutan Terhadap Propionibacterium acne.

Sriwijaya, S. dan D. H. (2013). Kajian Volume dan Frekuensi Penyiraman Air Terhadap Pertumbuhan dan Hasil Mentimun pada Vertisol. Jurna Agrisains, 4(7), 77-89.

Widjaja, A. dan Y. S. (2014). Analisa Persepsi Konsumen Tentang Atribut Produk AMDK. Jurnal Manajemen Pemasaran Petra, 2(1), 1 -8 . 